\title{
アミノグリコシドの腎特異的蓄積を規定する分子機構の解析とそれに基づく腎毒性 のない新規アミノグリコシド製剤開発の試み
}

永井純也

\section{Molecular Mechanisms Underlying Renal Accumulation of Aminoglycoside Antibiotics and Mechanism-based Approach for Developing Nonnephrotoxic Aminoglycoside Therapy}

\author{
Junya NAGAI \\ Department of Pharmaceutics and Therapeutics, Graduate School of Biomedical Sciences, \\ Hiroshima University, 1-2-3 Kasumi, Minami-ku, Hiroshima 734-8553, Japan
}

(Received February 20, 2006)

\begin{abstract}
Aminoglycoside antibiotics, such as gentamicin and amikacin, are a class of clinically important antibiotics used worldwide in the treatment of infections caused by Gram-positive and Gram-negative bacteria. However, nephrotoxicity and ototoxicity are serious problems in the use of aminoglycosides and are the major dose-limiting side effects. Most of the intravenously administered dose is excreted into the urine, whereas some of the aminoglycoside injected (about 10\% of the dose) is selectively accumulated in the renal cortex, leading to renal injury. Aminoglycosides are taken up into the epithelial cells of the renal proximal tubules by an endocytic pathway. Acidic phospholipids, broadly distributed in the plasma membranes in various tissues, were considered to be the binding site of aminoglycosides. Recently, megalin, a giant endocytic receptor abundantly expressed in renal proximal tubules, has been reported to bind aminoglycosides. Therefore we first examined whether megalin plays an important role in the renal accumulation of aminoglycosides under in vivo and in vitro conditions. We then attempted to develop new strategies for preventing the nephrotoxicity of aminoglycosides based on the molecular mechanisms of aminoglycoside accumulation in the kidney. This review summarizes our recent findings ol the role of megalin in the renal accumulation of aminoglycosides and our approach to develop nonnephrotoxic aminoglycoside therapy.
\end{abstract}

Key words — aminoglycoside antibiotics; receptor-mediated endocytosis; nephrotoxicity; megalin; basic peptides

1. はじめに

ゲンタマイシン (GM) やアミカシン (AMK) に代表されるアミノグリコシド系抗生物質 (AGs) は, 緑膿菌を含むグラム陰性菌に対し優れた抗菌活 性を有し，世界的にみても重要な抗菌薬である。ま た最近では，AGsであるアルベカシンは数少ない MRSA 治療薬の 1 つとして臨床において重要な位 置を占めている。しかし，AGsの投与によって， 比較的高頻度に腎毒性や聴器毒性が惹起することが 広く知られており，その警戒心から薬効が十分に期 待できる場合においても，処方が控えられる場合が 少なくない. AGs 投与によって誘発される腎毒性

広島大学大学院医歯薬学総合研究科（T734-8553 広島 市南区霞 1-2-3)

e-mail: jnagai@hiroshima-u.ac.jp

本総説は，平成 17 年度日本薬学会中国四国支部奨励賞

の受賞を記念して記述したものである.
は，その腎挙動と密接に関係していると考えられて いる。すすおち，生体内に投与された AGs は腎皮 質に選択的かつ高濃度に移行し（投与量の約 10 \%)，またその蓄積が長期間に渡ることによって AGs の腎毒性が誘発されるものと考えられてい る.これまでの数多くの研究から, AGsの腎移行 にはレセプター介在性エンドサイトーシスが関与す ることが示されてきた。 また，そのレセプターとし て生体膜脂質である酸性リン脂質の関与が示唆され ていた。しかし，AGsが腎選択的に蓄積すること を説明するには不十分であり，腎に特異的に存在す るレセプターの関与が不可欠と考えられていたもの の，長らく不明のままであった。近年，腎近位尿細 管上皮細胞の管腔側に高発現しているエンドサイ トーシスレセプター・メガリン（Fig. 1) が，AGs と親和性を有することが報告された. ${ }^{1-3)}$ これを契 機として，筆者らは AGs の腎移行におけるメガリ 


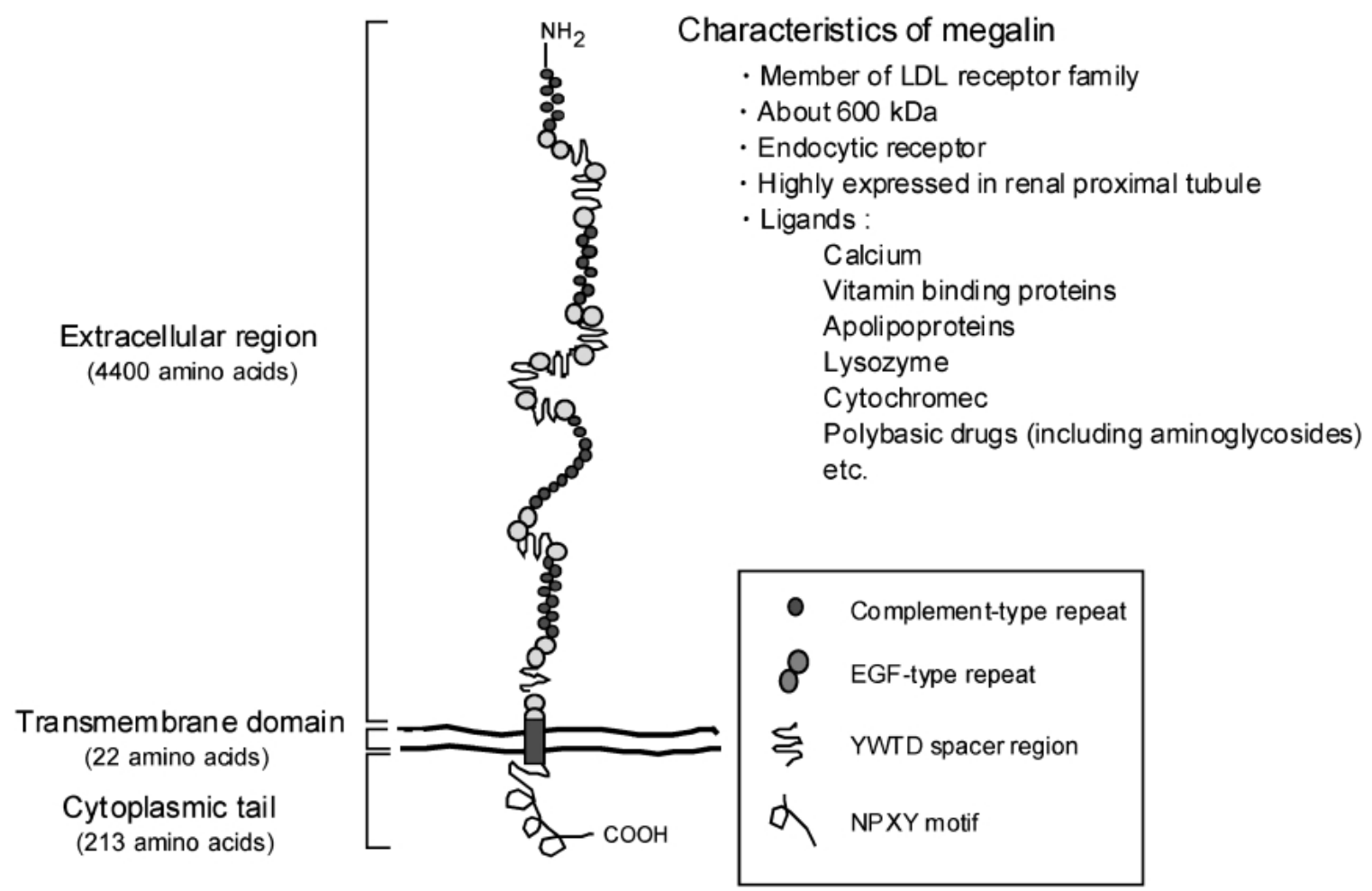

Fig. 1. Schematic Representation and Characteristics of Megalin, an Endocytic Receptor

ンの役割を明確にするため，ラットやマウスを用い た in vivo レベル及び培養腎上皮細胞や単離細胞膜 などを用いた in vitro レベルでの解析を開始した。 さらに，それらの解析によって得られた基礎的知見 に基づき，AGs 腎取り込みに関与するレセプター を分子標的とした AGs の腎移行制御法の開発を進 めている. ${ }^{4)}$ 本総説では, これらの研究によって得 られた成果について紹介する。

\section{AGs の腎移行におけるメガリンの関与5,6)}

AGs の体内動態におけるメガリンの関与を解析 していく上で，メガリンの組織発現分布を調べるこ とは不可欠である。しかし，その解析に必要なメガ リンの抗体は市販されていなかったため, メガリン 抗体を作製することから実験を開始した。メガリン は low-density lipoprotein (LDL) レセプターファ ミリーに属しており，その細胞外領域は同じ LDL レセプターファミリーのメンバーである LDL receptor-related protein（LRP-1）と高い相同性を示 す。一方で，細胞内領域においては，LDL レセプ ターファミリーを含めクラスリン介在性のエンドサ イトーシスレセプターに共通して存在する NPXY モチーフを除き，レセプター間の相同性は低い．そ こで，メガリンの細胞内領域の部分ペプチドを抗原
として白色家鬼に投与したところ，メガリンを特異 的に認識する抗血清を得ることに成功した。この抗 血清を用い，メガリンの組織発現分布をWestern blotting によって解析したところ，メガリンの組織 発現量は，腎皮質で最も高く，ついで腎髄質であ り，脳，肺，肝では検出されなかった（Fig. 2 (A))。 あわせて，静脈内投与した AMK の組織移 行性について調べたところ，AMK の静脈内投与後 120 分における組織移行は，腎皮質，ついで腎髄質 であり，腎乳頭，脳，肺，肝における移行は検出さ れなかった（Fig. 2(B))。このように，メガリンの 組織発現分布と AMK の組織移行性とが，良好な相 関を示すことが観察された。

次に，ファンコニー症候群の実験モデルであるマ レイン酸投与ラットにおいて，腎尿細管に発現して いるメガリンが脱落することが報告されていたこと から, 7) 筆者らはこのマレイン酸投与ラットが AGs の腎移行におけるメガリンの関与を解析する上で有 用な動物モデルではないかと考え，これを用いてア ミノグリコシドの腎移行解析を試みた。 まず，メガ リンがマレイン酸投与によって脱落することを確認 するため，腎皮質と尿サンプルについて Western blotting を行った結果，マレイン酸投与によって腎 
(A)

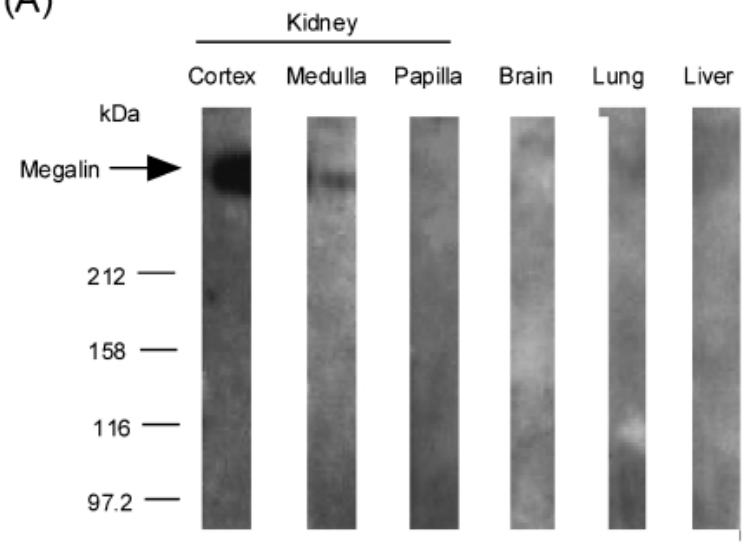

(B)

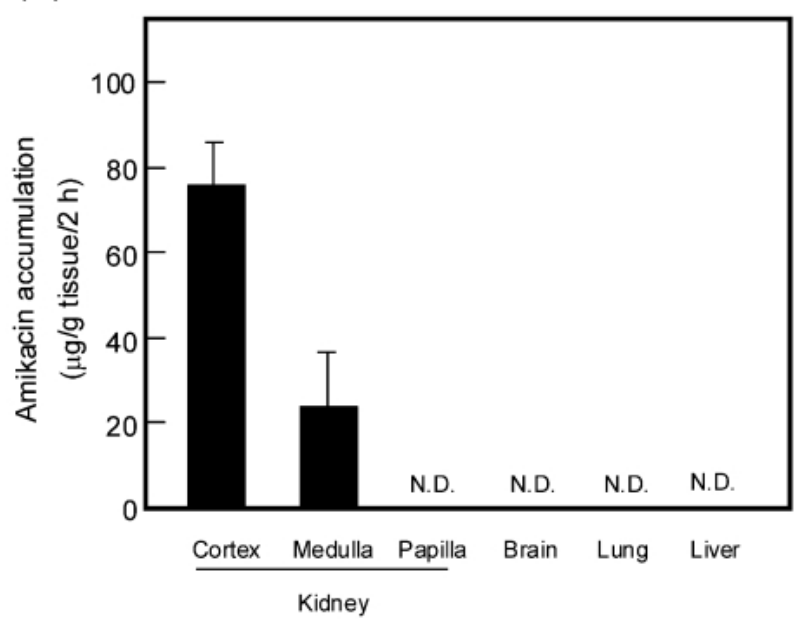

Fig. 2. Western Blot Analysis of Rat Tissue Homogenates with Anti-megalin Antiserum (A) and Tissue Distribution of Amikacin after Intravenous Administration to Rats (B) (from Ref. 5)

Values are expressed as mean \pm S.E. of results from three to five rats. N.D.: not detected.

皮質のメガリンレベルが低下し，一方で，尿中にメ ガリンが出現してくることを認めた。 そこで，マレ イン酸投与後の様々な時間に AMK を投与し, 腎皮 質のメガリンレベルと AMK の腎皮質移行性につい て比較解析した。 その結果, マレイン酸投与によつ て，速やかに腎皮質のメガリンレベルが低下すると ともに，腎皮質への AMK 移行量も減少した。ま た，メガリンレベルの回復に伴って，AMKの腎皮 質移行量も対照群と同程度にまで回復することが観 察された（Fig. 3)。このように，腎皮質のメガリ ンレベルと AMK の腎皮質移行性とが良好に対応す ることが示された.

メガリンの生理的な役割の 1 つとして，糸球体ろ 過されたタンパク質の尿細管再取り込みが挙げられ
(A)

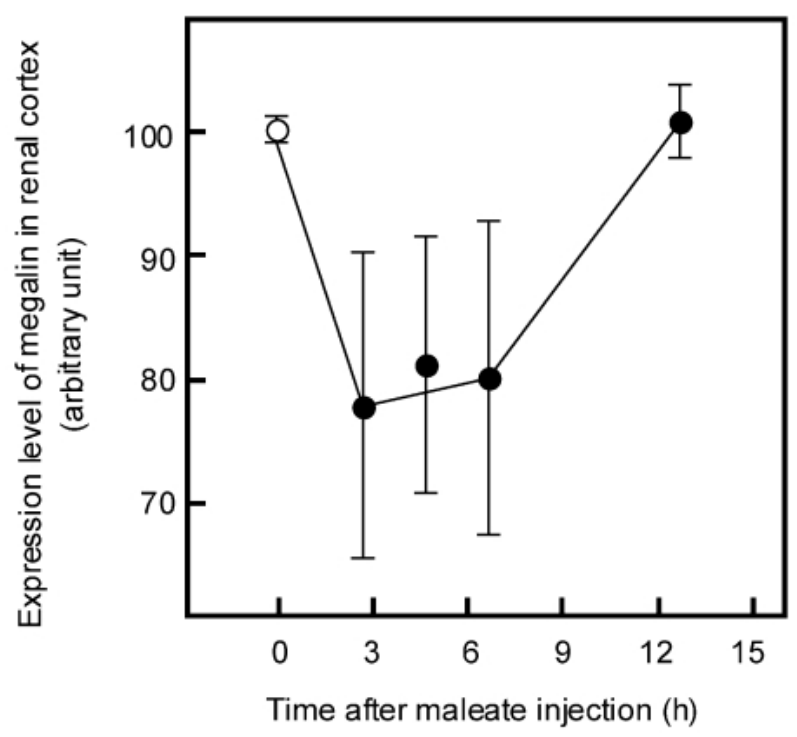

(B)

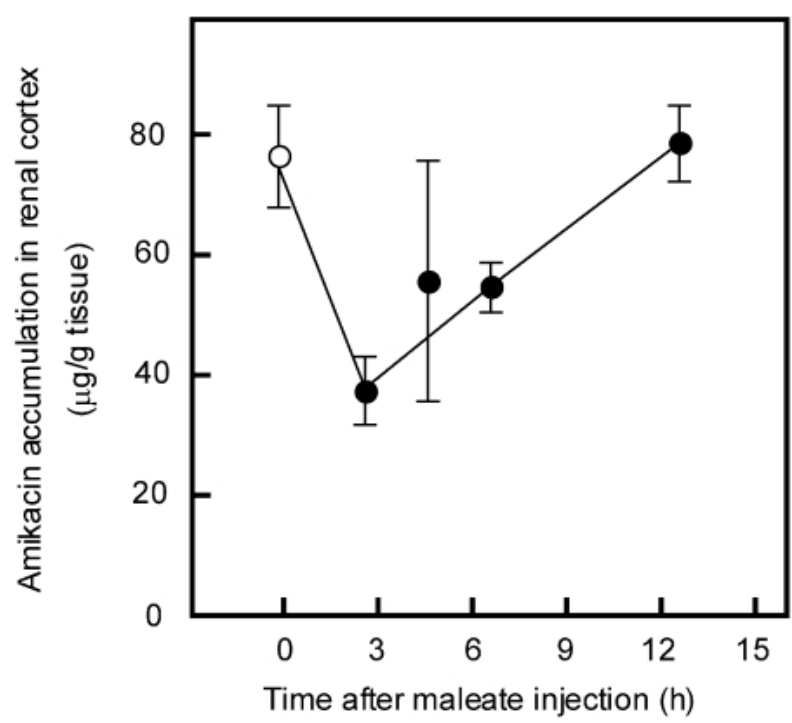

Fig. 3. Time Profile of Megalin Level and Amikacin Accumulation in Rat Renal Cortex after Maleate Injection (from Ref. 5)

Open circle: normal rats, closed circle: maleate-treated rats. Values are expressed as mean \pm S.E. of results from three to five rats.

る、したがって，AGsがメガリンを介して尿細管 に取り込まれるのであれば，AGsを投与すること によって糸球体ろ過されたタンパク質の再取り込み が阻害されるものと考えられる。 そこで，近位尿細 管においてメガリンを介して取り込まれるビタミン $\mathrm{D}$ 結合タンパク質 $(\mathrm{DBP})^{8)}$ の尿中排泄量に及ぼす $\mathrm{GM}$ 投与の影響について検討した。 その結果，対照 群に比べ，GM 投与群において DBP の尿中排泄が 
上昇することが観察された（Fig. 4(A))。また， GM 持続注入時にメガリンのリガンドであるリゾ チームの FITC 標識体を投与し，その尿中あるいは 胆汁中排泄量を測定した。 その結果，対照群に比べ, GM 投与群における FITC- リゾチームの尿中排泄 量は有意に増加したが (Fig. 4(B))，胆汁中排泄量 への影響は観察されなかった。これら DBP やリゾ

(A)

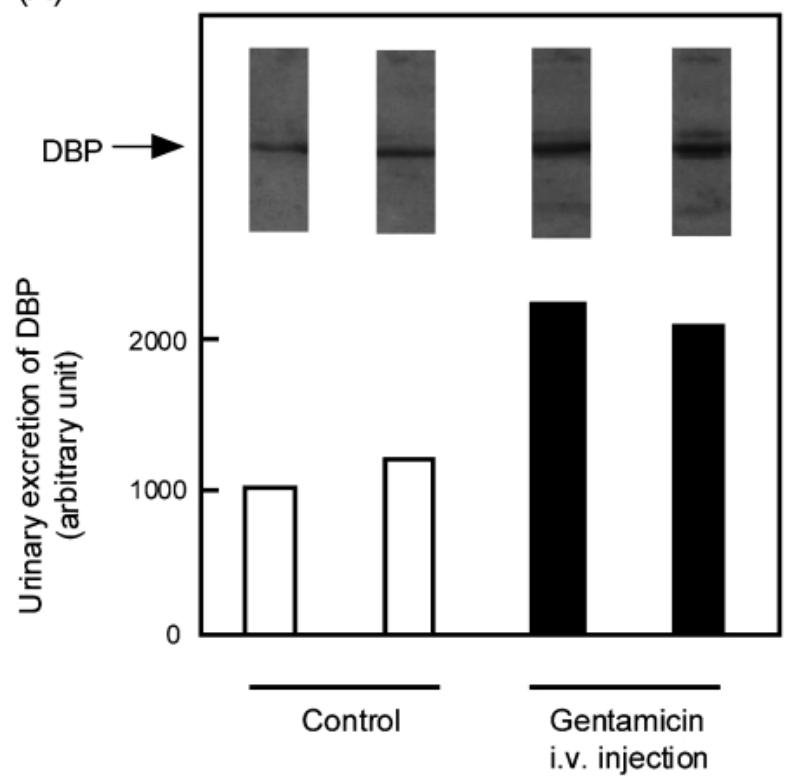

(B)

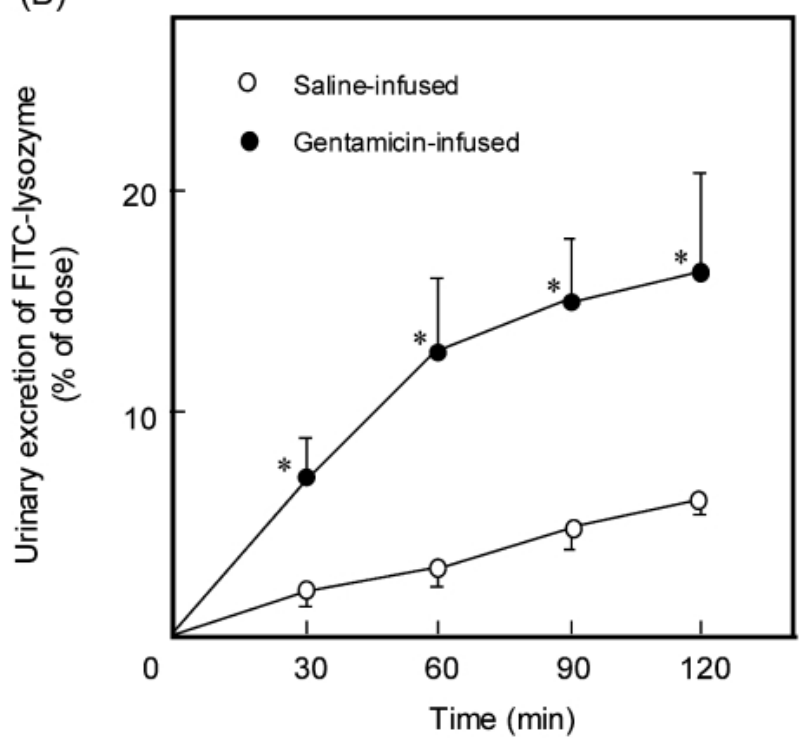

Fig. 4. Effect of Gentamicin on Urinary Excretion of Endogenous Vitamin D Binding Protein (DBP) (A) and Intravenously Injected FITC-lysozyme (B) (from Refs. 5 and 6)

(A) Values are expressed as optical density determined for each DBP band using NIH image software. (B) Open circle: saline-infused group, closed circle: gentamicin-infused group. Values are expressed as mean \pm S.E. of results from four or five rats. ${ }^{*} p<0.05$, significantly different compared with the value for the saline-infused group.
チームを用いた実験から，GMは尿細管再取り込み において，メガリンリガンドと競合するものと考え られた。また，Schmitz ら9)の報告によれば，メガ リンをノックアウトしたマウスでは $\left[{ }^{3} \mathrm{H}\right] \mathrm{GM}$ の腎 移行は投与量の $0.6 \%$ に過ぎず，対照群の $10.6 \%$ に 比べて，著しく低いことが示されている，したがっ て，これらの in vivo を中心とした一連の解析結果 から，AGsの腎蓄積にメガリンが重要な役割を果 たしていることが明確となつた。 そこで次に，メガ リンを分子標的とすることで AGs の腎移行を阻害 し，ひいては腎毒性を防御できるか否かについて検 討を進めた。

\section{3.メガリンを分子標的とした AGs の腎移行 .} 毒性防御10)

メガリンを分子標的としたストラテジーを模式的 に示す（Fig. 5)。すなわち，AGs とメガリンリガ ンドを併用投与することによって，メガリンへの結 合を抑制することができれば，AGs は腎尿細管上 皮細胞内に取り込まれることなく尿中に排泄され， 腎毒性を防御できるものと考えられる。そこで, $\left[{ }^{3} \mathrm{H}\right] \mathrm{GM}$ 投与時にチトクローム $\mathrm{C}$, リゾチームや アプロチニンなどの各種メガリンリガンドを併用投 与したところ， $\left[{ }^{3} \mathrm{H}\right] \mathrm{GM}$ の腎皮質移行が抑制され ることが示された（Fig. 6(A))，さらに，併用する チトクローム C の投与量を変化させたところ，用 量依存的に $\left[{ }^{3} \mathrm{H}\right] \mathrm{GM}$ の腎移行が低下することが観 察された（Fig. 6(B)).

メガリンリガンドの併用投与によって GM の腎 移行が低下することが示されたことから，実際に GM によって誘発される腎毒性が軽減されるか否か を，尿細管障害マーカーである $N$ - アセチル - $\beta$-Dグルコサミニダーゼ（NAG）の尿中排泄量を指標 に調べた。 その結果，GM 投与によって上昇した尿 中 NAG 排泄量は，チトクローム $\mathrm{C}$ の併用投与に よって対照群と同程度にまで低下することが観察さ

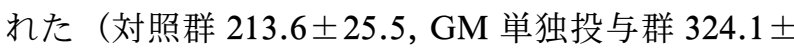
$23.8, \mathrm{GM} /$ チトクローム $\mathrm{C}$ 併用群 $229.7 \pm 22.5 \mathrm{mU} /$ day, $n=3)$ ．したがつて，メガリンリガンドを併用 投与する手法によって， AGs の腎移行のみなら ず，腎毒性も軽減できることが明らかになった。

しかし，併用剤のヒトでの投与量を体重換算で求 めると，AGsの腎移行を抑制するためには数グラ ムという高用量のチトクローム $\mathrm{C}$ を静脈内投与す 


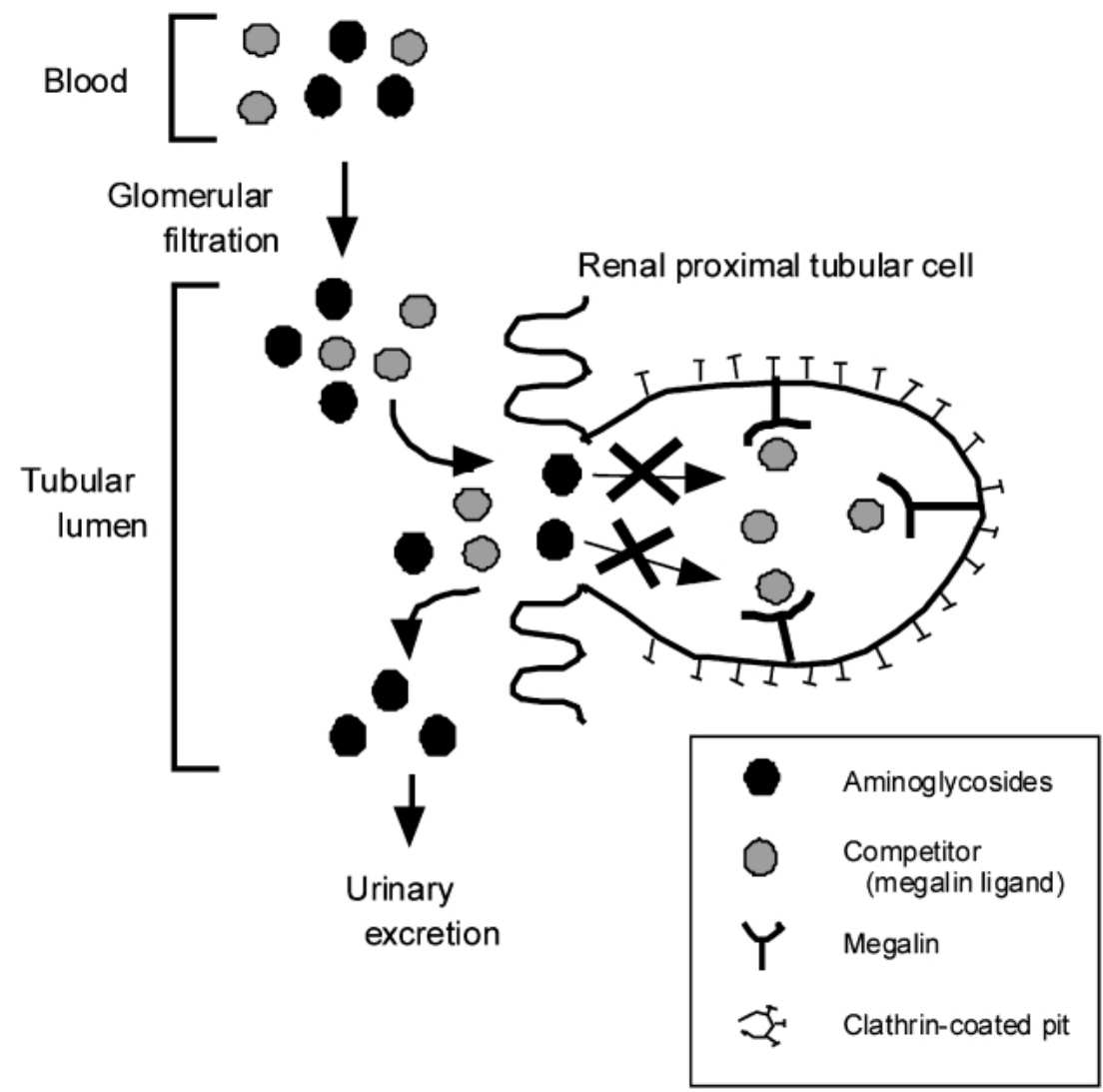

Fig. 5. A Scheme for Megalin-targeted Prevention of Renal Accumulation of Aminoglycosides by Coadministration of Megalin Ligands

る必要があることになる。これだけの高用量を投与 することは臨床において難しいと考えられるため, 併用剂の用量を下げるための研究へと展開した。筆 者らはまず, チトクローム C のアミノ酸配列からメ ガリンとの相互作用に必要と予想される領域を選び 出し，阻害効果を維持したまま分子量を下げること ができれば，用量の低下に繋がるものと考えた。メ ガリンリガンドの多くは塩基性領域を有しており, その塩基性領域がメガリンの酸性アミノ酸に富む領 域に結合することが示唆されている。そこで，チト クローム $\mathrm{C}$ のアミノ酸配列において塩基性アミノ 酸に富む領域である, 79 番目から 88 番目の 10 アミ ノ酸からなるペプチド Cyto79-88 (KMIFAGIKKK) を設計した。 まず，メガリンが発現している培養腎 上皮細胞 $\mathrm{OK}^{11)}$ における $\left[{ }^{3} \mathrm{H}\right] \mathrm{GM}$ の細胞内取り込 みに及ぼすCyto79-88 の影響について調べた結 果, チトクローム $\mathrm{C}$ による濃度依存的な $\left[{ }^{3} \mathrm{H}\right] \mathrm{GM}$ 取り込みの阻害効果に比べて, Cyto79-88 による 阻害効果は左にシフトし，より低濃度で $\left[{ }^{3} \mathrm{H}\right] \mathrm{GM}$ 取り込みを阻害することが観察された（Fig. 7
(A)). そこで, in vitro で観察されたペプチドフラ グメント化による阻害効果の増強が，in vivo でも 認められるかどうかについて検討した。しかし，in vivo の場合には，チトクローム C で十分に $\left[{ }^{3} \mathrm{H}\right]$ GM の腎移行阻害効果が観察される用量においても, Cyto79-88 による効果は観察されなかった（Fig. 7 (B)). そこで，in vivo においても効果を発揮でき るぺプチドについてさらなる探索を進めた.

4. 塩基性ペプチド N-WASP181一200 及びその 改変ペプチドによる AGs 腎移行阻害効果 ${ }^{10,12)}$

N-WASP181—200 は, neural Wiskott-Aldrich syndrome protein (N-WASP) と呼ばれるアクチン調 節タンパク質の 181 から 200 番目のペプチドである (Table 1)。このペプチドに着目した理由は，NWASP181一200 がメガリンとの相互作用に重要な 要因である塩基性のペプチドであることに加え，古 くからアミノグリコシドの腎取り込みレセプターで あることが指摘されている酸性リン脂質と結合する ことから, ${ }^{13)}$ より強力な AGs の腎移行阻害効果を 期待できると考えたためである。 
(A) $\quad\left[{ }^{3} \mathrm{H}\right]$ Gentamicin accumulation in rat renal cortex ( $\mu \mathrm{g} / \mathrm{g}$ tissue/2 h)

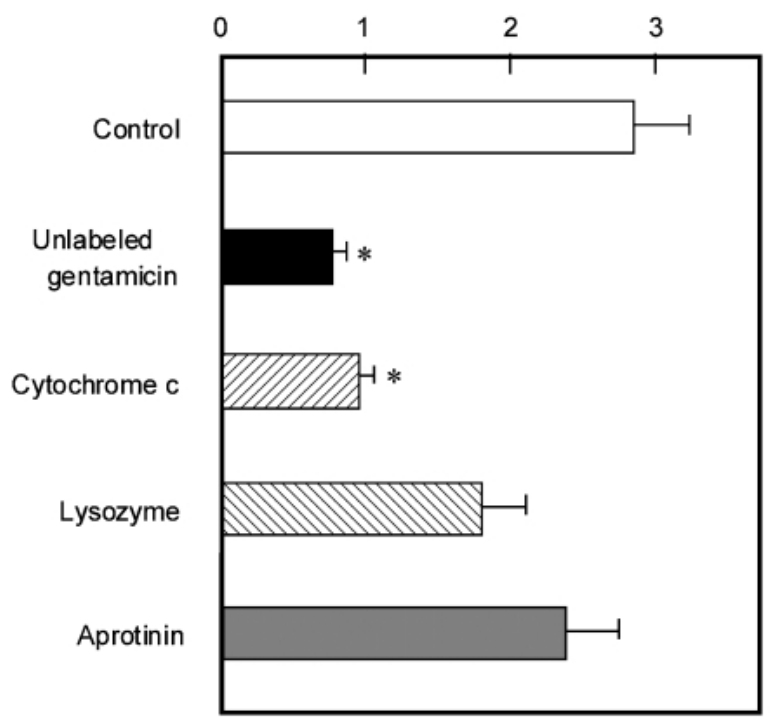

(B)

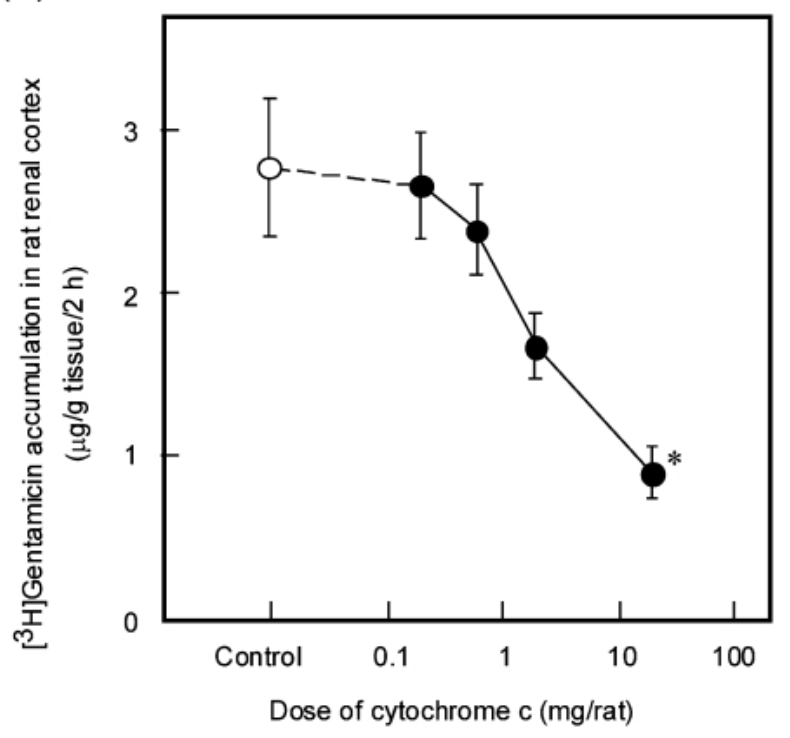

Fig. 6. Effects of Coadministration of Various Megalin Ligands (A) and Dose-dependent Effect of Cytochrome c (B) on $\left[{ }^{3} \mathrm{H}\right]$ Gentamicin Accumulation in Rat Renal Cortex (from Ref. 10)

Values are expressed as mean \pm S.E. of results from three rats. ${ }^{*} p<0.05$, significantly different compared with the value for control.

\section{まず，N-WASP181一200による $\left[{ }^{3} \mathrm{H}\right] \mathrm{GM}$ 腎移} 行阻害効果について, in vitro と in vivo で評価し た。その結果，N-WASP181一200 は，培養腎上皮 細胞 $\mathrm{OK}$ における $\left[{ }^{3} \mathrm{H}\right] \mathrm{GM}$ の取り込みを濃度依存 的に阻害し，その阻害効果は，それまでに使用した 併用物質の中で最も強いものであった（Fig. 8 (A))。また, N-WASP181一200 は in vivoにおい

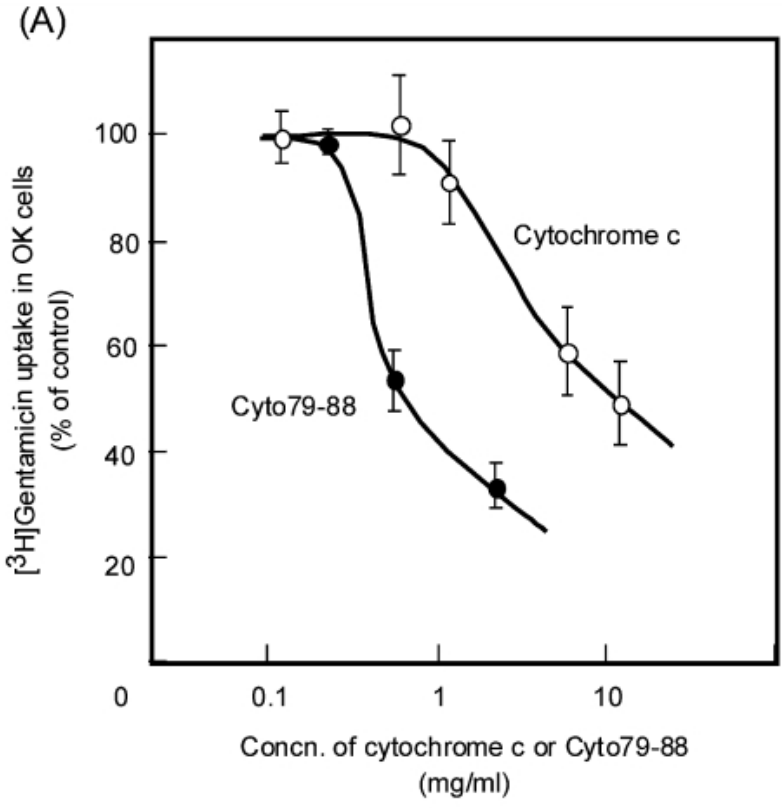

(B)

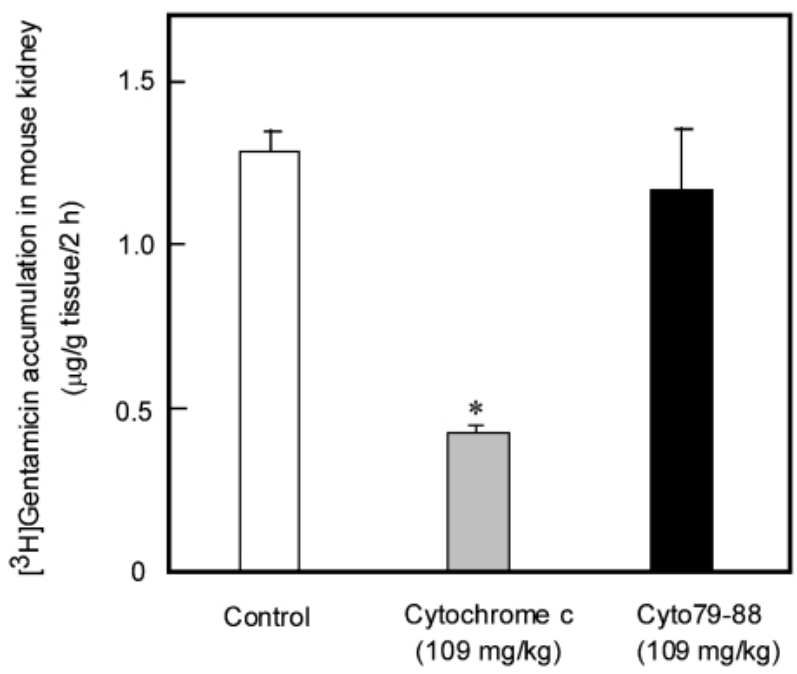

Fig. 7. Effects of Cytochrome c and Its Fragment Peptide Cyto79-88 on $\left[{ }^{3} \mathrm{H}\right]$ Gentamicin Uptake in OK Kidney Epithelial Cells Expressing Megalin (A) and Renal Accumulation in Mice (B) (from Ref. 10)

(A) Values are expressed as mean \pm S.E. of results from three monolayers. (B) Values are expressed as mean \pm S.E. of results from three mice. ${ }^{*} p<$ 0.05 , significantly different compared with the value for control.

ても，[ $\left.{ }^{3} \mathrm{H}\right] \mathrm{GM}$ の腎移行を投与量依存的に阻害す ることが観察された（Fig. 8(B)）.

次に, N-WASP181-200 の効果をさらに高める ことを目的として，その配列に含まれるアミノ酸に 着目した. メガリンを含む LDL レセプターファミ リーのメンバーに共通して存在する ligand binding repeat と呼ばれる領域には, Ser-Asp-Glu からなる SDE モチーフが繰り返して存在し，このSDE モ 
Table 1. Sequences, Net Charges, $\mathrm{IC}_{50}$ Values for $\left[{ }^{3} \mathrm{H}\right]$ Gentamicin Binding to Rat Renal Brush-border Membrane and Ellipticities at $222 \mathrm{~nm}$ of N-WASP181-200 and Its Mutant Peptides (from Ref. 12)

\begin{tabular}{clccc}
\hline \hline Peptide & Sequence & Net charge & $\begin{array}{c}\text { IC } \\
(\mathrm{mm}) \text { value }\end{array}$ & $\begin{array}{c}\text { Ellipticity at } 222 \mathrm{~nm} \\
\left(\mathrm{deg} \cdot \mathrm{cm}^{2} \cdot \mathrm{dmol}^{-1}\right)\end{array}$ \\
\hline N-WASP181-200 & NISHTKEKKKGKAKKKRLTK & +10 & $0.041 \pm 0.0001$ & $4.34 \times 10^{3}$ \\
N-W (K9G, K15G) & NISHTKEKGKGKAKGKRLTK & +8 & $0.078 \pm 0.009$ & $1.77 \times 10^{3}$ \\
N-W (K9E, K15E) & NISHTKEKEKGKAKEKRLTK & +6 & $0.043 \pm 0.009$ & $3.47 \times 10^{3}$ \\
N-W (E7K) & NISHTKKKKKGKAKKKRLTK & +12 & $0.034 \pm 0.003$ & $4.74 \times 10^{3}$ \\
\hline
\end{tabular}

(A)

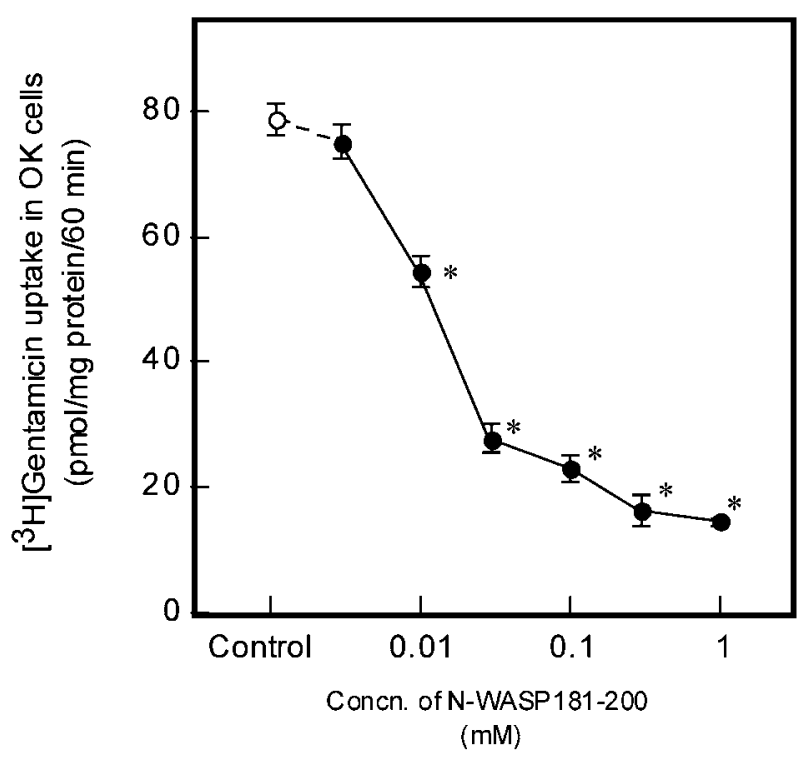

(B)

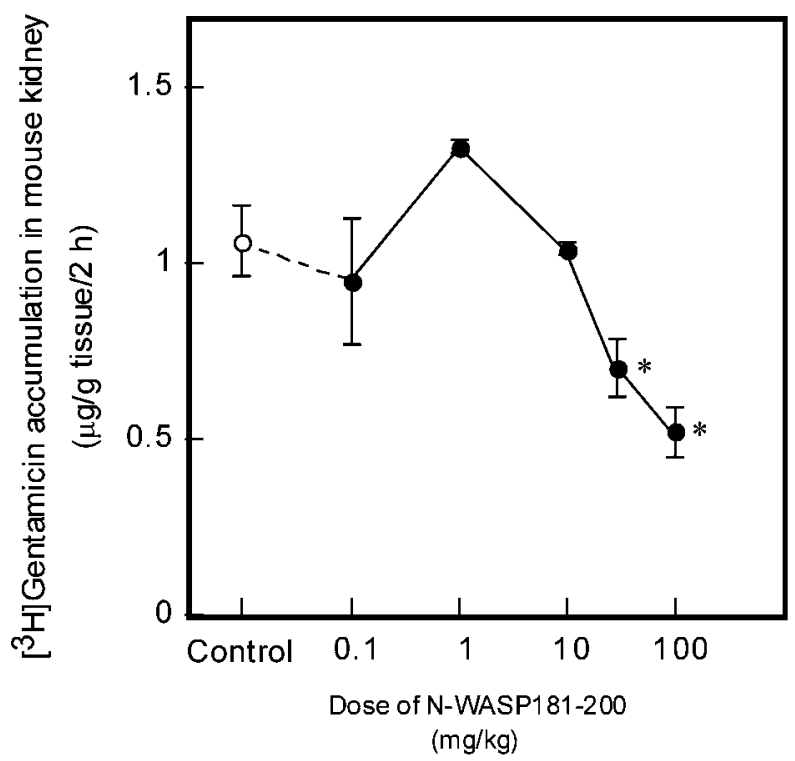

Fig. 8. Effect of N-WASP181-200 on $\left[{ }^{3} \mathrm{H}\right]$ Gentamicin Uptake in OK Cells (A) and Renal Accumulation in Mice (B) (from Ref. 10)

(A) Values are expressed as mean \pm S.E. of results from three monolayers. ${ }^{*} p<0.05$, significantly different compared with the value for control. (B) Values are expressed as mean \pm S.E. of results from three mice. ${ }^{*} p<$ 0.05 , significantly different compared with the value for control.
チーフによって形成される酸性領域がリガンドの塩 基性領域との相互作用に重要であると考えられてい る. N-WASP181-200 のアミノ酸配列中には，塩 基性アミノ酸が 3 個以上連続する配列が 2 力所存在 する。 そこで，筆者らはこの塩基性アミノ酸からな るクラスターがメガリンの SDE モチーフとの相互 作用，ひいては AGs の腎移行阻害に重要な役割を 果たしているのではないかと考えた。この点につい て精查するため, Table 1 に示す 3 種の改変ペプチ ドをデザインした， N-W $(\mathrm{K} 9 \mathrm{G}, \mathrm{K} 15 \mathrm{G})$ は 7 番目と 15 番目の塩基性アミノ酸 $\mathrm{Lys}$ を中性アミノ酸 $\mathrm{Gly}$ に置換したもの，N-W(K9E，K15E) は同部位を酸 性アミノ酸である Glu に置換したものであり，さ らに N-WASP181-200 に比べより塩基性を高める ために, 配列内唯一の酸性アミノ酸である 7 番目の Glu を Lys に置換した N-W（E7K）を合成した. $\left[{ }^{3} \mathrm{H}\right] \mathrm{GM}$ の腎刷子緑膜結合に及ぼす 3 種の改変ぺ プチドの影響について，親ぺプチドである $\mathrm{N}-$ WASP181-200 と比較したところ, いずれの改変 ペプチドによっても濃度依存的な阻害効果が観察さ れた，Hill 式を用いて算出した各ペプチドの $\mathrm{IC}_{50}$ 值を Table 1 に示す。その結果, Gly 置換した NW (K9G, K15G) の IC 50 值は N-WASP 181一200に 比べて上昇し, 阻害効果の低下が観察された。一方, $\mathrm{N}-\mathrm{W}(\mathrm{E} 7 \mathrm{~K})$ の $\mathrm{IC}_{50}$ 值は N-WASP181一200に比べ て低下し，ペプチドの塩基性を高めることによって $\left[{ }^{3} \mathrm{H}\right] \mathrm{GM}$ 結合に対する阻害効果が強まることが観 察された，その一方で，2つの塩基性アミノ酸を酸 性アミノ酸に置換した N-W (K9E，K15E）では，予 想に反して， $\mathrm{IC}_{50}$ 值の変化はほとんど観察されな かった，したがって，ペプチドの塩基性アミノ酸数 から酸性アミノ酸数を差し引いた net charge の違い だけでは， $\mathrm{IC}_{50}$ 值の変化は説明できないものと考 えられた。

そこで，筆者らはペプチドの二次構造が $\left.{ }^{3} \mathrm{H}\right]$ 
GM 結合阻害効果に関与しているのではないかと想 定し, 各ぺプチドの高次構造について解析を進め た。まず，各ペプチドについて，二次構造予測サー バ（PredictProtein server）を用いて構造予測を行 ったところ，親ペプチドである N-WASP181-200, $\mathrm{N}-\mathrm{W}(\mathrm{K} 9 \mathrm{E}, \mathrm{K} 15 \mathrm{E}), \mathrm{N}-\mathrm{W}(\mathrm{E} 7 \mathrm{~K})$ では $\alpha$-ヘリックス 構造を有するが，阻害効果の低下を示した $\mathrm{N}-\mathrm{W}$ $(\mathrm{K} 9 \mathrm{G}, \mathrm{K} 15 \mathrm{G})$ のみが $\alpha$-ヘリックスを形成しない ものと推定された。そこで，実際に各ぺプチドの二 次構造についての情報を得るため, 円二色性 (CD) スペクトルを測定した。その結果，N-WASP181200 の CD スペクトルは，222 nm 付近に極小值を 示す $\alpha-$ ヘリックス構造に特徵的なパターンを示し た. 各ペプチドについて， $\alpha$-ヘリックス含量の指 標とされる $222 \mathrm{~nm}$ における棈円率 $[\theta]$ を算出し た結果を Table 1 に示す，その結果， $\left[{ }^{3} \mathrm{H}\right] \mathrm{GM}$ 結合 阻害効果が低下した N-W $(\mathrm{K} 9 \mathrm{G}, \mathrm{K} 15 \mathrm{G})$ の $\alpha$-ヘリ ックス含量は, 他の 3 種のペプチドに比べて低いこ

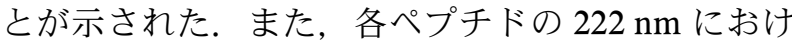
る棈円率 $[\theta]$ と $\mathrm{IC}_{50}$ 值との相関関係を調べたとこ ろ，有意に相関のある直線関係が得られた $(\mathrm{r}=$ $0.96, p<0.05)$ 。これらの結果から，より強力な AGs 腎移行阻害効果を発揮させるためには，ペプ チドが $\alpha$-ヘリックス構造を有することが不可欠で あることが示唆された，興味あることに，メガリン リガンドでもあるアポリポプロテイン E (apo-E) と LDL レセプターとの結合において, apo-E の塩 基性に富む receptor binding domain が $\alpha$-ヘリック ス構造を形成することが，両者の相互作用に重要で

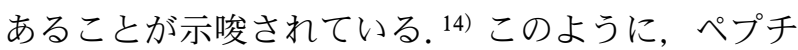
ドの二次構造も考慮することで，より AGs 腎移行 阻害活性の高いペプチドを設計できるものと考えら れる。

\section{5. おわりに}

最初の AGs であるストレプトマイシンが発見さ れて以来 60 年以上が経つが，現在でも AGs は感染 症治療に不可欠な抗菌薬である。しかし，有効血中 濃度域の幅が狭く，臨床において TDM（therapeutic drug monitoring) の対象となる薬物である。こ れまでに数多くなされてきた AGs の抗菌作用や体 内動態に関する研究から，AGs の 1 日 1 回投与法 （once-daily dosing）が，分割投与法に比へ，有効 性，安全性及び経済性などにおいて優れているとさ
れている。一方，AGs の腎毒性をより確実に防御 するためには，AGsの腎移行を完全に阻害するこ とが最も確かな手段であるものと考えられる，本研 究では, AGs の腎移行の分子機構について解析を 進め，その分子機構に基づき AGs の腎移行及び腎 毒性を防御するためのドラッグデリバリーシステム の開発に取り組んできた。 また，本研究の成果に基 づき，AGs 腎毒性防御剂としての有用性が期待で きる N-WASP181-200関連ペプチドについて特許 化を進めている（特開 2003-261459, 特願 2005一 016132)。しかし，こうした研究成果を実用化にま で到達させるためには，それらぺプチドの安全性な ぞ，検討すべき課題が数多く残されている. 特に, 動物実験から予想すると, AGs の腎移行阻害効果 を発揮するためにヒトにおいて必要とされる併用剂 の用量は，これらぺプチドでも数百ミリグラム以上 と見積もられ，その用量を低減させるためのさらな る研究が不可欠である. 今後, ペプチドの体内動態 を制御することで腎指向性を高めていくことなどを 目的とした in vivo 研究とともに，より低濃度で AGs 腎移行阻害効果を発揮するぺプチドを設計し ていくための in vitro 研究を進め, 両者のバランス に優れたペプチドあるいはその誘導体を開発してい きたいと考えている.

謝辞本研究は広島大学大学院医歯薬学総合研 究科医療薬剂学研究室, 高野幹久教授のご指導の下 で行ったものであり，この場を借りて心から感謝申 し上げます。また，貴重なご助言を賜りました広島 国際大学薬学部，村上照夫教授に厚くお礼申し上げ ます。さらに，多大なご協力を頂きました広島大学 大学院医歯薬学総合研究科医療薬剂学研究室湯元良 子博士をはじめ，卒業生及び在学生の皆様に深謝致 します。

\section{REFERENCES}

1) Saito A., Pietromonaco S., Loo A. K., Farquhar M. G., Proc. Natl. Acad. Sci. U.S.A., 91, 9725-9729 (1994).

2) Christensen E. I., Birn H., Nat. Rev. Mol. Cell Biol., 3, 256-266 (2002).

3) Moestrup S. K., Cui S., Vorum H., Bregengård C., Bjørn S. E., Norris K., Gliemann J., Christensen E. I., J. Clin. Invest., 
96, 1404-1413 (1995).

4) Nagai J., Takano M., Drug Metab. Pharmacokinet., 19, 159-170 (2004).

5) Nagai J., Tanaka H., Nakanishi N., Murakami T., Takano M., Am. J. Physiol. Renal Physiol., 281, F337-F344 (2001).

6) Nagai J., Katsube T., Murakami T., Takano M., J. Pharm. Pharmacol., 54, 1491-1496 (2002).

7) Bergeron M., Mayers P., Brown D., Am. J. Physiol. Renal Physiol., 271, F908-F916 (1996).

8) Nykjaer A., Dragun D., Walther D., Vorum H., Jacobsen C., Herz J., Melsen F., Christensen E. I., Willnow T. E., Cell, 96, 507-515 (1999).
9) Schmitz C., Hilpert J., Jacobsen C., Boensch C., Christensen E. I., Luft F. C., Willnow T. E., J. Biol. Chem., 277, 618-622 (2002).

10) Watanabe A., Nagai J., Adachi Y., Katsube T., Kitahara Y., Murakami T., Takano M., J. Control. Release, 95, 423-433 (2004).

11) Takano M., Nakanishi N., Kitahara Y., Sasaki Y., Murakami T., Nagai J., Kidney Int., 62, 1707-1717 (2002) .

12) Nagai J., Saito M., Adachi Y., Yumoto R., Takano M., J. Control. Release, (2006) (in press).

13) Prehoda K. E., Scott J. A., Mullins R. D., Lim W. A., Science, 290, 801-806 (2000).

14) Mahley R. W., Science, 240, 622-630 (1988). 